\title{
USING A DIGESTAMIN AS A FEED ADDITIVE IN EGYPTIAN BUFFALO COWS (Bubalus bubalis) DIETS
}

\author{
Sh.A. Gabr ${ }^{1}$; A.M. EL-Hais ${ }^{1}$; A.A. Gabr ${ }^{1}$; Shimaa, M. El- Komy ${ }^{1}$ and Hala, M. Khfaga ${ }^{1}$ \\ ${ }^{1}$ Animal Production Department, Faculty of Agriculture, Mansoura University, Mansoura, Egypt.
}

\section{SUMMARY}

$\mathrm{T}$ This current work was performed to estimate the milk production and composition, blood parameters and some reproductive properties of Egyptian buffalo cows (Bubalus bubalis) fed a digestamin as feed additive. A total of 27 Egyptian buffalo cows were used in this study. The experimental buffaloes aged 4-8 years between the 2 nd and $5^{\text {th }}$ parity at late pregnancy (one month pre partum). Three main experimental basal diets were formulated from corn silage, berseem hay, rice straw and concentrate feed mixture containing $14 \% \mathrm{CP}$ and digestsmin was added at $0,0.1$, and $0.5 \%$ of DM, respectively. The current study showed that, increasing digestamin supplementation in buffalo cows diets increased significantly $(\mathrm{P}<0.01)$ average milk yield, total solids, fat, lactose, protein. On the other hand, there was a significant decrease $(\mathrm{P}<0.01)$ in milk total solid not fat, ash and somatic cells count by increasing digestamin supplementation to $0.5 \%$ level. Increasing digestamin levels also, significant increased $(\mathrm{P}<0.01)$ blood total protein, albumin and total lipids. Oppositely, there was a significant decrease $(\mathrm{P}<0.01)$ blood plasma globulin, glucose, AST and ALT concentration with increasing digestamin levels. The experimental diets with digestamin recorded the higher $(\mathrm{P}<0.01)$ calf birth, calf birth at weaning, daily weight gain compared to other experimental diets, while the higher body weight and placenta weight of buffalo cows were obtained by control buffalo cows. Generally, there was a significant improved $(\mathrm{P}<0.01)$ in reproduction parameters of the experimental buffalo cows by digestamin supplementation. It could be concluded that, digestamin as a feed additive can improve the growth, productive and reproductive performance of Egyptian buffalo cows (Bubalus bubalis). So, it could be used in diets of Egyptian buffalo (Bubalus bubalis) especially with $0.5 \%$ of DM.

Keywords: Digestamine, Growth, Reproduction, Blood parameters and Egyptian buffalo cows (Bubalus bubalis).

\section{INTRODUCTION}

The scarcity of animal feeds particularly protein sources is a serious problem faces the animal breeders which result in low productivity and reproductive performance of farm animals. Soybean meal $(\mathrm{SBM})$ is most widely used as a protein source for ruminants feeding. Soybean meal has many beneficial prosperities such as high crude protein (44\% to $49 \%$ ), rich source of lysine, tryptophan, threonine, isoleucine, and valine which are seriously deficient in cereal grains. The presence of raw SBM in ruminants feeding in high quantities had been restricted because many of the anti-nutritional factors contains anti-nutritional factors such as antigens, oligosaccharides, lectins, and trypsin inhibitors that decrease nutrient availability and reduce growth performance of farm animals especially young one (Li et al., 1991; Hong et al., 2004). So, it is believed that, using fermented soybean meal (FSBM) which devoid the pervious anti-nutritional factors is more efficient in ruminants feeds without inhabiting growth performance (Jones et al., 2010).

Digestamin is one of natural feed additives which include Lactic acid fermented soybean, lactic acid fermented dried grass from natural pastures rich in herbs, dried horse radish roots, and Lactic acid fermented oak bark shavings. The high quality dietary fiber from the fermented grass contained in digestamin is very important for the digestive hygiene of the animals and very helpful for young animals to build up an optimal working digestive system. Soya, used as a fermentation substrate, is converted by the fermentation and additionally different metabolites, like short chain peptides, which are known to enhance mucosal immunity and thereby the general health, are produced. The horseradish also contained in digestamin has a positive influence on the immune- and digestive system, and it is also a very effective agent against respiratory diseases (Piro, 2000) of animals. In the meantime, buffalo is the second global milk-producing animal all over the world. It could produce about 90 
million tons in 2009 which contributing about $13 \%$ of the total world milk production with an annual growth rate of $3.1 \%$ as compared to $1.3 \%$ for cow milk (CM) production (IDF 2010). Additionally, buffalo milk is richer in almost all the main milk nutrients compared to cow milk (CM). Also, some milk products such as Mozarrella cheese and ghee are the specialties of buffalo milk. So, the main aims of this study is estimating the effect of digestamin as feed additive on milk production and composition, blood parameters and some reproductive properties of Egyptian buffalo (Bubalus bubalis).

\section{MATERIALS AND METHODS}

The experimental work of this study was carried out at El-Gemmizah Research Station, Gharbia Governorate, belonging to the Animal Production Research Institute (APRI), Agricultural Research Center, Ministry of Agriculture in participation with Department of Animal Production Faculty of Agriculture, Tanta University, during the period from 1 May 2014 to 30 of April 2015.

\section{Experimental animals and diets:}

A total of 27 Egyptian buffalo cows aged 4-8 years between the 2 nd and $5^{\text {th }}$ parity. Were at late pregnancy (one month prepartum) were assigned to three groups balanced for live body weight (LBW), milk yield; parity and age. Three main experimental basal diets were formulated from corn silage (CS), berseem hay (BH), rice straw (RS) and concentrate feed mixture (CFM) containing $14 \% \mathrm{CP}$. The experimental diets were fed to experimental animals according to NRC (1985) for Egyptian buffaloes nutritional requirements. Digestamin was obtained from Produktionsgemeinschaft F.U.H. Egger GmbH Company; Austria was added to the CFM of ration of the D1, D2 and D3 groups at $0,0.1$ and $0.5 \%$ of DM, respectively. Buffalo cows in all groups were fed the experimental rations for about month prepartum on the basis of their expected birth date till 4 months lactation period. Animals were housed in open pens and fed in groups. Fresh and clean drinking water was available at all times The animals were fed on the following tested diets

1- The control group (D1): $\mathrm{CS}+\mathrm{BH}+\mathrm{RS}+\mathrm{CFM}$.

2- $\quad$ The $1^{\text {st }}$ treated group (D2): $\mathrm{CS}+\mathrm{BH}+\mathrm{RS}+\mathrm{CFM}$ plus $0.1 \%$ digestamin.

3- The $2^{\text {nd }}$ treated group (G3): $\mathrm{CS}+\mathrm{BH}+\mathrm{RS}+\mathrm{CFM}$ plus $0.5 \%$ digestamin.

Chemical compositions of the experimental feed stuffs are shown in table (1). Animals were housed in open pens and fed in groups. Fresh and clean drinking water was available at all times. At the start of the experiment, the quantity of CFM, BH, RS and CS were fed in restricted amounts being 6, 4, 4 and 9 $\mathrm{kg} \mathrm{DM} / \mathrm{h} / \mathrm{d}$, respectively. The CFM was offered twice daily just before milking at $6 \mathrm{a} . \mathrm{m}$. and before the second milking at 4 p.m. The amount of RS was divided into two equal parts and given at 7 a.m. and 4 p.m. The amount of CS was divided into two equal parts and offered at 8 a.m. and 5 p.m. All buffalo cows were allowed to nurse their calves for the first four days postpartum (period of colostrum intake). Thereafter, they were milked in the absence of their calves' twice-daily at.6 a.m. and 5 p.m. throughout the lactation period. Buffalo cows in all groups were fed the experimental rations for about month prepartum on the basis of their expected birth date till 4 months lactation period.

\section{Experimental procedure:}

\section{Body condition score and milk production:}

Throughout the feeding period, body condition score (BCS) as changes in live body weight was monthly recorded for each animal. Milk yield was individually recorded twice daily at 6 a.m. and afternoon at 5 p.m. throughout lactation period of 4 months. Representative monthly samples from milk were taken from evening and morning milk for determination of fat protein, lactose and total solids. The $4 \%$ fat corrected milk (4\% FCM) for each buffalo cow was calculated from milk yield according to the following formula: $4 \% \mathrm{FCM}=$ Actual milk yield $(\mathrm{kg}) \times 0.4+0.15 \times$ fat yield $(\mathrm{kg})$ Geans equation, (cited by Abou-Raya, 1967).

\section{Blood sampling:}

Blood samples through postpartum period up to pregnancy were collected twice weekly immediately before feeding at 3 days interval via jugular vein from all buffalo cows. However, biochemical parameters in blood plasma were determined in monthly samples. Sampling started from 10 days postpartum for four months (experimental period). Within an hour after collection, samples were centrifuged for 15 minutes at $3000 \mathrm{rpm}$ for plasma separation, which was stored at $-20 \mathrm{oC}$ until analysis. 


\section{Placental drop and uterine involution:}

The time required for complete placental drop in each animal was immediately calculated. The reproductive tract of each animal was rectally palpated once /two day till 21 day postpartum and once/three days after that, to assess the uterine involution according to El-Fadaly (1978). Live body weight of calves at birth was recorded individually after parturition.

\section{Observation of oestrus:}

Buffaloes in all groups were visually observed for oestrus behavior using teaser bull introduced for 3 times /day at 6:00, 12.00 and $4.00 \mathrm{~h}$. The teaser bull was allowed to run with females for 30 minutes on each occasion. The following symptoms were used as indicators for oestrus, including response to teaser bull, bellowing, segregation and restlessness, standing female, frequent urination, response to finger massage and vaginal mucous discharge. The following signs were recorded for male behavior sniffing the vulva following the female, resting chin on female rump, mounting the females and standing for mounting by bull.

\section{Reproductive parameters:}

Postpartum first ovulation interval (PPFVI) was determined by subtracting four days from the time at which plasma progesterone concentration reached the level of $<0.5 \mathrm{ng} / \mathrm{ml}$ that was sustained for two consecutive samples. This was based on the finding on changes in P4 concentration to oestrus and ovulation as reported by Aboul-Ela (1992) and Avenell et al. (1985). Time of the 1st occurrence of standing postpartum oestrus was recorded as postpartum first oestrus interval (PPFOI). Buffaloes that were detected in standing oestrus were served naturally by a fertile bull and then postpartum first service interval (PPFSI) was recorded. Rectal palpation was performed $60 \mathrm{~d}$ after date of service for pregnancy diagnosis, thereafter length of days open (DO), service period (SP), and number of service per conception (NS/C) were recorded. Conception rate was determined as percentage of buffaloes diagnosed pregnant proportional to the total number of buffaloes served. This was recorded for the 1st, 2nd and 3rd service. Gestation period (GP) was recorded as an interval from conception date to parturition date. Yet, calving interval (CI) was computed as gestation period length plus days open.

\section{Biochemical parameters:}

Concentration of total protein $(\mathrm{g} / \mathrm{dl})$, albumin $(\mathrm{g} / \mathrm{dl})$, glucose $(\mathrm{mg} / \mathrm{dl})$ and total lipids $(\mathrm{g} / \mathrm{dl})$ in plasma were photometrically determined using spectrophotometer (6405 UV/VIS) and commercial kits. According to Gornall et al. (1949), Weichselaum (1946), Trinder (1969) and Zollner and Kirch (1962), respectively. However, concentration of globulin was computed by subtracting concentration of total protein from albumin., Activity of glutamic oxaloacetic (ALT) and glutamic pyruvic transaminase (AST) were estimated according to Varoly (1976).

\section{Statistical analysis:}

All data were subjected to statistical analysis according to the procedures reported by Sendector and Cochran (1982) using computerized analysis system (SAS 2004), Significant differences among means were set at $\mathrm{P}<0.05$ using Duncan's multiple range test (Duncan, 1955).

\section{RESULTS AND DISCUSSION}

\section{Milk production and composition:}

The current study showed that, increasing digestamin level supplementation in buffalo cows diets increased significantly $(\mathrm{P}<0.01)$ average milk yield, total solids, fat, lactose and protein (Table 2$)$. On the other hand, there was a significant decrease $(\mathrm{P}<0.01)$ in milk total solid not fat, and somatic cells count by increasing digestamin level supplementation to $0.5 \%$ level. However, there no significant effect $(\mathrm{P}<0.01)$ was detected by digestamin supplementation on milk ash.

Digestamin is one of natural feed additives which include Lactic acid fermented soybean, lactic acid fermented dried grass from natural pastures rich in herbs, dried horse radish roots, and Lactic acid fermented oak bark shavings. Wanapat et al. (2011b) explained that milk yield was remarkably improved when yeast-fermented cassava chip (YEFECAP) was fed at 16-28\% DM in concentrate during early lactation period (30 DIM) of dairy cows. While, no differences were obtained in milk 
production (Wanapat et al., 2011a) when YEFECAP was used during the early lactation period (18 DIM).

\section{Blood parameters:}

Results in table (3) explained that, increasing digestamin levels increased $(\mathrm{P}<0.01)$ blood total protein, albumin and total lipids (Table 3). On the other hand, there was a significant decrease $(\mathrm{P}<0.01)$ in blood, glucose, AST and ALT concentration with increasing digestamin levels. Kwon et al. (2011) showed that, total serum Ig A and IgM levels significantly increased in both FSBM groups compared to un supplemented one. It could be suggest that, FSBM may have lower concentrations of allergenic and anti nutritional factors than the soybean meal which improve kidney and liver function of experimental animals (Wolfswinke, 2009). The presence of micro-organisms in fermented soybean meal may helper factor to enhance intestinal tract and liver health in digestion and absorption which reflex on normal blood components of experimental buffalo cows.

\section{Growth performance:}

Results of Table (4) clearly indicated that, the addition of digestamin recorded the highest $(\mathrm{P}<0.01)$ calf birth, calf birth at weaning, daily weight gain compared to the control with $0.5 \%$ levels $(41.1 \mathrm{~kg}$, 119.0 and $742.16 \mathrm{~g} /$ day, respectively, While the lowest were obtained by control buffalo cows (30.83, 69.50 and $621.89 \mathrm{~kg}$, respectively). Fermentation by bacteria such as lactobacillus could be decreases peptide size by releasing proteases and peptidases during fermentation that aid in the breakdown of complex nutrients in soy protein which accompanied with more nutrients utilization and enhancing growth performance of experimental calves (Hong et al., 2004). In the meantime, Min et al. (2009) reported that, FSBM maybe work as a growth promoter through its higher supply of essential amino acids and possibly vitamins synthesized during the fermentation. Also, Kim et al. (2009) reported that, fermented soybean meal can be used as replacer for animal-derived protein sources containing plasma protein and dried skim milk in piglet nursery diets without hazards effects on growth performance of the piglets.

\section{Reproduction indices:}

Results in Table (5) showed, a significant decrease $(\mathrm{P}<0.01)$ in the lested reproduction parameters of the experimental buffalo cows by digestamin supplementation. The supplemented diet with $0.5 \%$ of digestamin had the lowest value of uterine horns symmetry, uterine involution, first post-partum estrus days open period and time of placenta dropping $(28.33,18.17,32.67,47.17$ days and $3.50 \mathrm{hr}$, respectively, Sapbamrer et al. (2013) explained that, the dietary fermented soybean amount might be an important factor for enhancing the reproductive hormones, lipids, and glucose. They found remarkable and a significant increase of progesterone in the experimental group supplemented with fermented soybean. Also, Cederroth et al. (2012) reported that, in humans there is a modest suppressant influence of soy and iso- flavone exposure on the hypothalamic-pituitary-gonadal axis.

\section{CONCLUSION}

It could be concluded that, digestamin as a feed additive can improve the growth, productive and reproductive performance of Egyptian buffalo cows (Bubalus bubalis). So, it could be used in diets of Egyptian buffalo (Bubalus bubalis) especially with $0.5 \%$ of DM.

\section{REFERENCES}

Abou-Ela, M. B. (1992). Oestrus detection and reproductive management of buffaloes raised in small holding in Egypt. Proceedings in the Mediterranean and the Middle East. Cairo, Egypt, Nov. 9-12, pp. 381-384.

Abou-Ray, A. K. (1967). Animal and Poultry Nutrition, 1st, Edit. Pub. Dar-El-Maarif. Cairo (Arabic Text Book).

Abraham, G.E. (1981) . Hand Book of Radio immunoassay, Marcel Dekker.

A.O.A.C. (1980) . Official methods of analysis (13 th ED) Association of official analytical chemists Washington D.C. 
Avenell, J. A. ; Saepudin, Y. and Fletcher, I. C. (1985). Concentration of LH, estradoil-17 $\beta$ and progesterone in the peripheral plasma of swamp buffalo cows (Bubalus bubalis) around time of oestrus. J. Reprod, Fert. 74: 419-424.

Cederroth, C.R., C. Zimmermann and S. Nef (2012). Soy, phytoestrogens and their impact on reproductive health.

Dabson,H. and P.Kaman, (1986).Areview of femal cattle reproduction with special reference to comparison between buffalo, cow and zebu.J.Reprod. Fert.77:1.

Duncan, D. B. (1955). Multiple rang and multiple F test. Biometrics 11: 1-42.

El-Fadaly, M. A. (1978). Some studies on the puerperium in buffaloes. M. D. Vet. Thesis, Cairo Univ., Egypt.

Gornall, A.G.; G.J.Bardawill and M.M.David,(1949). J.Biol.Chem.177:751.C.F.Hartmam and Lascelles(1965).

Gwazdauskas, F.C.;T.L.Bibb ;M.L.;Megilliard and J.A.Lineweaver,(1979):Effect of prepartum, vitamin E injection on time for placenta to pase and production function.,J Dairy Sci. 62 :978.

Hong, K. J., C. H. Lee, and S. W. Kim (2004). Aspargillus Oryzae GB-107 fermentation improves nutritional quality of food soybeans and feed soybean meals. J. Medicinal Food 7:430-436.

IDF (2010) The World Dairy Situation 2010. Bulletin of the IDF No. 446/2010. International DairyFederation, Brussels, Belgium

Jones CK, DeRouchey JM, Nelssen JL, Tokach MD, Dritz SS, Goodband RD. Effects274 of fermented soybean meal and specialty animal protein sources on nursery pig 275 performance. $\mathrm{J}$ AnimSci 2010; 88: 1725-1732.

Kim, S. W., E. van Heugten, F. Ji, C. H. Lee, and R. D. Mateo (2009). Fermented soybean meal as a vegetable protein source for nursery pigs: I. Effects on growth and performance of nursery pigs. J. Animal Sci. 87: in print.

Kwon, I. H., M. H. Kim, C. Yun, J. Y. Go, C. H. Le,e , H. J. Lee, W. P. and J. K. Ha1(2011). Effects of Fermented Soybean Meal on Immune Response of Weaned Calves with Experimentally Induced Lipopolysaccharide Challenge. Asian-Aust. J. Anim. Sci. 24(7 ) : 957 - 964

Li, D.F.; J.L. Nelssen; P.G. Reddy; F. Blecha; R.D. Klemm; D.W. Giesting; J.D. Hancock; G.L. Allee; R.D. Goodband. Measuring suitability of soybean products for early-weaned pigs with immunological criteria.J. Anim. Sci. 1991, Vol. 69, 3299-3307.

Min, B. J., J. H. Cho, Y. J. Chen, H. J. Kim, J. S. Yoo, Q. Wang, I. H. Kim, W. T. Cho and S. S. Lee. (2009). Effects of replacing soy protein concentrate with fermented soy protein in starter diet on growth performance and ileal amino acid digestibility in weaned pigs. Asian-Aust. J. Anim. Sci. 22(1):99-106.

NRC (1985): Nutrient Requirements of dairy cattle (6th ED).National Academy press, Washington.D.C.

Sapbamrer, R., N. Visavarungroj and M. Suttajit (2013). Effects of dietary traditional fermented soybean on reproductive hormones, lipids, and glucose among postmenopausal women in northern Thailand. Asia Pac J Clin Nutr ;22 (2):222-228.

SAS (2004). SAS user's guide. Statistical Analysis System. Institute, Inc. Cary., NC.

Smith,J.C.;G.P. Burtimoritz and W.C.Purdy (1979). Direct measurements of zinc in plasma by atomic absorbtion spectroscopy, Clim.Chem.,25: 1487.

Snedecor, G.W. and W.G. Cochran (1982). Statistical Methods. 7th Ed. Iowa Univ. Press, Ames. Iowa, USA.

Tricia, L. Wolfswinke (2009). The effects of feeding fermented soybean meal in calf starter on growth and performance of dairy calves. Graduate Theses and Dissertations. Paper 11061.

Trinder ,P (1969) .Determination of blood glucose using an oxidase-peroxidase system with a noncarcinogenic chromogen.J.Clin.Path.22,158-161.

Varoley, V. (1976).Practical clinical biochemistry.4th Edition, New Delhi,India.

Wanapat,M.,K.Boonop.,A.Cherdthong (2011b). Effect of alternative protein sources on rumen microbes and productivity of Dairy cows. MJ. Int, Sci. Tech.,5 (1): 13-23.

Wanapat,M.,S.Polyarach.,V.Chanthakhoum.,N.Sornsongern (2011a). Yeast fermented cassava chip protein concentration for lactating Dairy cows fed on urea-lime treated rice strow.Lives Sci.,139,258-263.

Wany W.(1922). Determination of blood hemoglobin. Biol.Chem.,77:409.

Weichselaum,T.E. (1946).Method for determination of albumin in serum blood, Amer.J.Clin.Pathol.,16:40. 
Zollner, n. and Kirch, K. (1962). Determination of total lipids. Ges. Exp. Med., 135:545.

استخدام الايجستامين كاضافة غذائية لعلاثق ابقار الجاموس المصرى

شريف عبد الونيس جبر، عبد العزيز محمد الحايس ،أحمد عبد الونيس جبر ،شيماء محمد الكومى وهالة محمد خفاجة

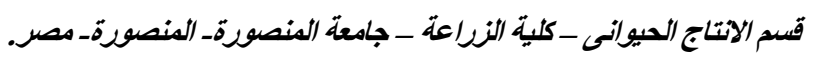

اجريت الدراسة الحالية بهدف معرفة تاثير اضافة الديجستامين الى علائق ابقار الجاموس المصرى على على انتاج ومكونات اللبن

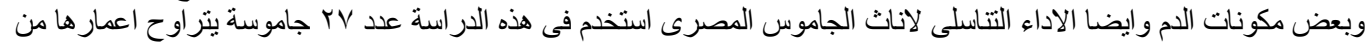

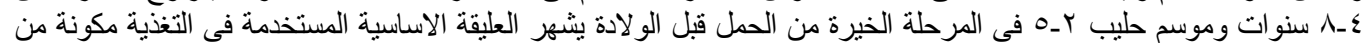

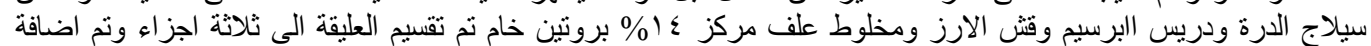

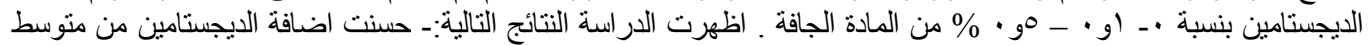

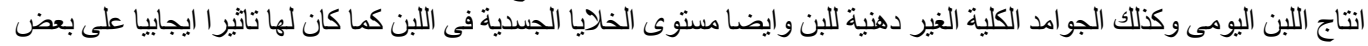

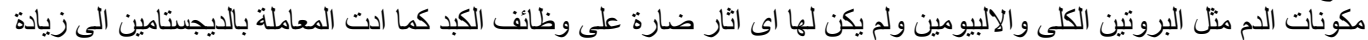

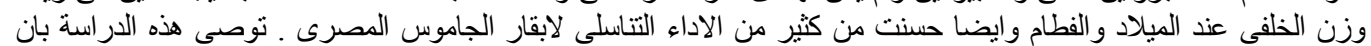

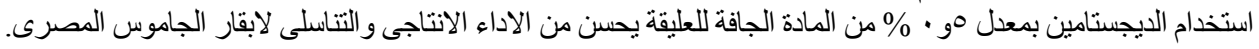


Table (1): Chemical analysis of the experimental feed stuffs (on DM basis).

\begin{tabular}{llllllll}
\hline \multirow{2}{*}{ Item } & \multirow{2}{*}{ DM\% } & \multicolumn{6}{c}{ Chemical composition on DM basis (\%) } \\
\cline { 3 - 7 } & & OM & CP & CF & EE & NFE & Ash \\
\hline Feedstuffs: & 88.40 & 78.36 & 2.96 & 35.83 & 2.23 & 37.34 & 21.64 \\
Rice straw (RS) & 86.70 & 87.10 & 15.50 & 30.93 & 2.13 & 38.54 & 12.90 \\
Berseem hay 3 $^{\text {rd }}$ cut (BH) & 36.06 & 87.58 & 9.43 & 26.64 & 2.73 & 48.87 & 12.42 \\
Whole corn silage (WCS) & 36.06 & 91.20 & 16.50 & 13.40 & 3.00 & 58.30 & 8.80 \\
Conc. Feed Mix. (CFM) & 90.00 & 90 &
\end{tabular}

Table (2): Effect of digestamin supplementation on total milk yield and milk component of buffalo cows after the $1^{\text {st }}$ week postpartum till $120^{\text {th }}$ day postpartum

\begin{tabular}{lcccccccc}
\hline \multicolumn{7}{c}{ Average } & \multicolumn{7}{c}{ milk yield and milk component } \\
$\begin{array}{l}\text { Treatment } \\
\text { group }\end{array}$ & $\begin{array}{c}\text { Average } \\
\text { milk } \\
\text { yield(kg) }\end{array}$ & $\begin{array}{c}\text { Total } \\
\text { solid } \%\end{array}$ & Fat \% & $\begin{array}{c}\text { lactose } \\
\%\end{array}$ & $\begin{array}{c}\text { Total } \\
\text { solid not } \\
\text { fat } \%\end{array}$ & $\begin{array}{c}\text { Protein } \\
\%\end{array}$ & $\begin{array}{c}\text { Ash \% } \\
\text { Comatic } \\
\text { Cells } \\
\text { account }\end{array}$ \\
\hline Control & 9.965 & 16.473 & 6.516 & 5.350 & 9.956 & 4.006 & 0.600 & 58.800 \\
$(\mathrm{D} 1)^{1}$ & $\pm 0.05^{\mathrm{c}}$ & $\pm 0.01^{\mathrm{c}}$ & $\pm 0.030^{\mathrm{c}}$ & $\pm 0.057^{\mathrm{a}}$ & \pm 0.02 & $\pm 0.05^{\mathrm{b}}$ & \pm 0.002 & $\pm 5.2^{\mathrm{a}}$ \\
$(0.1 \%)$ & 10.882 & 16.768 & 6.733 & 5.226 & 10.035 & 4.213 & 0.595 & 45.500 \\
$\begin{array}{l}\text { Digestamin } \\
\text { (D2) }\end{array}$ & $\pm 0.02^{\mathrm{b}}$ & $\pm 0.016^{\mathrm{b}}$ & $\pm 0.03^{\mathrm{b}}$ & $\pm 0.023^{\mathrm{b}}$ & \pm 0.01 & $\pm 0.02^{\mathrm{a}}$ & \pm 0.004 & $\pm 2.3^{\mathrm{b}}$ \\
$(0.5 \%)$ & 11.608 & 16.970 & 6.900 & 5.133 & 10.070 & 4.335 & 0.601 & 32.650 \\
$\begin{array}{l}\text { Digestamin } \\
(\mathrm{D} 3)^{3}\end{array}$ & $\pm 0.006^{\mathrm{a}}$ & $\pm 0.017^{\mathrm{a}}$ & $\pm 0.036^{\mathrm{a}}$ & $\pm 0.022^{\mathrm{b}}$ & \pm 0.03 & $\pm 0.03^{\mathrm{a}}$ & \pm 0.003 & $\pm 2.6^{\mathrm{c}}$ \\
\hline
\end{tabular}

$a, b$ and $c$ : Means within the same row with different superscripts are significantly different at $P<0.01$.

Table (3): Effect of digestamin supplementation on blood component of buffalo cows after the $1^{\text {st }}$ week postpartum till $120^{\text {th }}$ day postpartum

\begin{tabular}{lccccccc}
\hline \multirow{2}{*}{ Treatment group } & \multicolumn{7}{c}{ blood component concentrations (g/100 ml) } \\
\cline { 2 - 7 } & $\begin{array}{l}\text { Total } \\
\text { protein }\end{array}$ & Albumin & Globulin & Glucose & $\begin{array}{c}\text { Total } \\
\text { lipids }\end{array}$ & AST & ALT \\
\hline Control (D1) & 7.630 & 4.065 & 3.565 & 59.788 & 0.588 & 29.950 & 1.615 \\
& $\pm 0.01^{\mathrm{c}}$ & $\pm 0.01^{\mathrm{c}}$ & $\pm 0.01^{\mathrm{b}}$ & $\pm 0.1^{\mathrm{a}}$ & $\pm 0.03^{\mathrm{c}}$ & $\pm 0.2^{\mathrm{a}}$ & $\pm 0.02^{\mathrm{b}}$ \\
$(0.1 \%)$ & 7.916 & 4.238 & 3.658 & 57.805 & 0.773 & 23.166 & 2.128 \\
${\text { Digestamin }(\mathrm{D} 2)^{2}}^{2}$ & $\pm 0.01^{\mathrm{b}}$ & $\pm 0.01^{\mathrm{b}}$ & $\pm 0.02^{\mathrm{a}}$ & $\pm 0.02^{\mathrm{c}}$ & $\pm 0.004^{\mathrm{b}}$ & $\pm 0.07^{\mathrm{b}}$ & $\pm 0.01^{\mathrm{a}}$ \\
$(0.5 \%)$ & 8.051 & 4.470 & 3.581 & 57.128 & 0.940 & 17.116 & 2.076 \\
${\text { Digestamin }(\mathrm{D} 3)^{3}}^{3}$ & $\pm 0.01^{\mathrm{a}}$ & $\pm 0.01^{\mathrm{a}}$ & $\pm 0.04^{\mathrm{b}}$ & $\pm 0.01^{\mathrm{b}}$ & $\pm 0.008^{\mathrm{a}}$ & $\pm 0.1^{\mathrm{c}}$ & $\pm 0.02^{\mathrm{a}}$ \\
\hline
\end{tabular}

$a, b$ and $c$ : Means within the same row with different superscripts are significantly different at $P<0.01$. 
Table (4): Effect of digestamin supplementation on body weight, calf weight, daily weight gain of calves and placenta weight of buffalo cows.

\begin{tabular}{|c|c|c|c|c|}
\hline \multirow{2}{*}{$\begin{array}{l}\text { Treatment } \\
\text { group }\end{array}$} & \multicolumn{4}{|c|}{ Body Weight of cow ,calves and placenta weight (kg) } \\
\hline & Body weight (kg) & $\begin{array}{c}\text { Calf birth } \\
\text { weight }(\mathrm{kg})\end{array}$ & $\begin{array}{l}\text { Calf birth weight at } \\
\text { weaning }(\mathrm{kg})\end{array}$ & $\begin{array}{l}\text { Daily weight gain } \\
\text { (g/day) }\end{array}$ \\
\hline Control (D1) ${ }^{1}$ & $615 . .66 \pm 3.5$ & $30.83 \pm 0.8^{\mathrm{c}}$ & $96.50 \pm 1.2^{c}$ & $621.83 \pm 5.6^{\mathrm{c}}$ \\
\hline$(0.1 \%)$ & $614.16 \pm 5.6$ & $35.67 \pm 0.06^{\mathrm{b}}$ & $108.50 \pm 1.3^{\mathrm{b}}$ & $693.17 \pm 3.6^{\mathrm{b}}$ \\
\hline $\begin{array}{c}\text { Digestamin } \\
(\mathrm{D} 2)^{2} \\
(0.5 \%)\end{array}$ & $614.33 \pm 7.4$ & 41. $0 \pm 0.09^{\mathrm{a}}$ & $119.00 \pm 0.6^{\mathrm{b}}$ & $742.17 \pm 3.8^{\mathrm{a}}$ \\
\hline $\begin{array}{l}\text { Digestamin } \\
(\mathrm{D} 3)^{3}\end{array}$ & & & & \\
\hline
\end{tabular}

Table (5): Effect of digestamin supplementation on reproduction indices of buffalo cows after the $1^{\text {st }}$ week postpartum till $120^{\text {th }}$ day postpartum

\begin{tabular}{|c|c|c|c|c|c|c|}
\hline \multicolumn{7}{|c|}{ Reproduction parameters } \\
\hline $\begin{array}{l}\text { Treatment } \\
\text { group }\end{array}$ & $\begin{array}{c}\text { uterine } \\
\text { horns } \\
\text { symmetry } \\
\text { (day ) }\end{array}$ & $\begin{array}{c}\text { uterine } \\
\text { involution } \\
\text { (day) }\end{array}$ & $\begin{array}{c}\text { first post } \\
\text { partum } \\
\text { estrus (day) }\end{array}$ & $\begin{array}{l}\text { days open } \\
\text { period } \\
\text { (day) }\end{array}$ & $\begin{array}{l}\text { time of } \\
\text { placenta } \\
\text { dropping } \\
\text { (hours) }\end{array}$ & $\begin{array}{c}\text { Placenta } \\
\text { weight }(\mathrm{kg})\end{array}$ \\
\hline $\begin{array}{c}\text { Control (D1) }^{1} \\
(0.1 \%)\end{array}$ & $\begin{array}{l}38.333 \pm 0.4^{\mathrm{a}} \\
30.666 \pm 0.6^{\mathrm{b}}\end{array}$ & $\begin{array}{l}29.500 \pm 0.3^{\mathrm{a}} \\
21.333 \pm 0.3^{\mathrm{b}}\end{array}$ & $\begin{array}{l}53.166 \pm 2.3^{\mathrm{a}} \\
41.500 \pm 0.9^{\mathrm{b}}\end{array}$ & $\begin{array}{l}102.833 \pm 3.8^{\mathrm{a}} \\
73.833 \pm 2.8^{\mathrm{b}}\end{array}$ & $\begin{array}{l}7.000 \pm 0.5^{\mathrm{a}} \\
4.083 \pm 0.3^{\mathrm{b}}\end{array}$ & $\begin{array}{l}5.108 \pm 0.04^{\mathrm{a}} \\
4.641 \pm 0.01^{\mathrm{b}}\end{array}$ \\
\hline $\begin{array}{l}\text { Digestamin } \\
(\mathrm{D} 2)^{2}\end{array}$ & & & & & & \\
\hline $\begin{array}{c}(0.5 \%) \\
\text { Digestamin } \\
(\mathrm{D} 3)^{3}\end{array}$ & $28.333 \pm 0.4^{\mathrm{c}}$ & $18.166 \pm 0.5^{\mathrm{c}}$ & $32.666 \pm 1.1^{\mathrm{c}}$ & $47.166 \pm 3.3^{c}$ & $3.500 \pm 0.1^{\mathrm{b}}$ & $4.825 \pm 0.08^{b}$ \\
\hline
\end{tabular}

